\title{
SELECTIVE FACTORS AFFECTING CLONAL VARIATION IN THE FALL CANKERWORM ALSOPHILA POMETARIA (LEPIDOPTERA: GEOMETRIDAE)
}

\author{
DOUGLAS J. FUTUYMA, STEVEN L. LEIPERTZ ${ }^{1}$, and CHARLES MITTER ${ }^{2}$ \\ Department of Ecology and Evolution, State University of New York at Stony Brook, \\ Long /sland, New York 11794, U.S.A.
}

Received 13.x.80

SUMMARY

\begin{abstract}
Differences in the frequency of certain clonal genotypes of Alsophila pometaria exist between neighbouring stands of maple and oak, but cannot be detected between individual maple and oak trees within a mixed-species stand. Several genotypes differ in their capacity for survival on maple foliage, but no evidence of differential survival or growth was found on oak foliage. Melanisation of larvae in the later instars, which is associated with the attainment of lower body weight, is a response to interaction among larvae; the tendency to display this response differs among genotypes. The selective factors acting on the clonal polymorphism thus may include environmental heterogeneity and densitydependent selection. Because of larval dispersal, the mosaic of trees in a mixed-species forest is "fine-grained" environmental variation that is unlikely by itself to maintain clonal variation.
\end{abstract}

\section{INTRODUCTION}

POPULATIONS of parthenogenetically reproducing animals are more genetically diverse than was formerly supposed. Enzyme electrophoresis and other techniques have revealed genetic variation in parthenogenetic earthworms (Jaenike et al., 1980), sea anemones (Shick et al., 1979), fishes (Vrijenhoek, 1979), lizards (Parker and Selander, 1976; Cuellar, 1979), and many kinds of insects (Suomalainen et al., 1976). If selection maintains this diversity, it must be a form of diversifying selection such as frequencydependent selection or environmental heterogeneity, because clonal diversity cannot arise from the segregation of inferior homozygotes from superior heterozygotes. Few studies have identified selective factors that affect the diversity of asexually reproducing genotypes. Vrijenhoek (1978, 1979) and Scudday (1973) have described ecological differences among clones of fish and of lizards, but Jaenike et al. (1980) could discern no ecological differences between two common, widely distributed clones of the earthworm Octolasion tyrtaeum. Thus ecological differences among coexisting asexual genotypes cannot be presumed; some such genetic variation may be selectively neutral (Parker, 1979).

Mitter and Futuyma (1977) reported that populations of the fall cankerworm Alsophila pometaria (Lepidoptera: Geometridae) consist largely of females whose primary, and perhaps exclusive, mode of reproduction is parthenogenetic. Such females transmit intact to their all-female offspring the often highly heterozygous maternal genotypes, as determined by electrophoresis of three or four variable enzymes. Some fèmales reproduce

Present addresses: ${ }^{1}$ College of Fisheries, University of Washington, Seattle, Washington 98195, U.S.A. ${ }^{2}$ Division of Entomology, University of Maryland, College Park, Maryland 20742, U.S.A. 
sexually, producing offspring of both sexes, among which genetic segregation appears normal. Reproduction by the asexual female appears to require mating, although there is no paternal contribution to the offspring's genotype. We have recently made observations (Harshman and Futuyma, in preparation) suggesting the possibility that reproduction by at least some females may be facultatively sexual or asexual; nonetheless, it is clear that parthenogenesis is the prevalent origin of the several genotypes, identified by their electrophoretic profile at several loci, that comprise a large fraction of the population (Mitter et al., 1979).

Mitter et al. (1979) reported that several of the common asexual genotypes are strongly associated with woodlots differing in the species composition of the trees on which the larvae feed. They found that the genotype designated $\mathrm{A}$ was associated with stands of red maple (Acer rubrum), and B with stands of oak (Quercus, especially $Q$. velutina and $Q$. coccinea). Genotype $\mathrm{C}$ has been found most abundantly on the campus of the State University of New York at Stony Brook, Long Island, where it inhabits an oak-dominated stand in which red maple and black birch (Betula lenta) are also abundant. Because the average time of èg hatch in the spring differs among those genotypes in parallel with the average time of bud break of maple and oak, Mitter et al. (1979) suggested that phenological variation among hosts may constitute a selective factor maintaining genetic variation among, and perhaps within, local populations.

We report here our observations and experiments designed to explore the response of certain genotypes of Alsophila to different host species, the possible effect of environmental "grain" (Levins, 1968) on the pattern of differentiation, and differences among genotypes in their response to crowding. This report, part of an ongoing exploration of biological differences among the clonal genotypes of this species, provides evidence that clonal variation is affected both by variation in host plants and by environmental factors not associated with the host.

\section{LIFE HISTORY}

Like the European winter moth Operophtera brumata (see Varley and Gradwell 1956, 1968; Embree, 1965; Feeny, 1970), a convergently similar geometrid, the females of Alsophila are wingless and emerge in early winter (November and December on Long Island, New York) from pupation sites underground. There is no evidence that they discriminate among tree species (which are leafless at this time) as they climb trunks, where they mate with winged males and lay clusters of up to 250 eggs. At about the time of bud break (about 24 April to 2 May in our area) the larvae hatch and can be dispersed widely by wind, especially in the first instar, but also to some extent in the later instars. The species is polyphagous, fecding on foliage of at least eight families of trees in our area. Between about 25 May and 10 June in our area, the larvae drop to the ground, where they immediately burrow to pupate. The species is univoltine. Larvae in the last two of the four instars are highly variable in colour, ranging from green, through varying degrees of melanisation to uniform black. Melanised larvae are most frequent in dense populations; sparse populations consist almost entirely of green larvae. Populations on Long Island and elsewhere are often extremely dense and cause considerable defoliation. 
From trapping data, we have estimated that in the course of a single unexceptional autumn (1977), about 900 females may climb an averagesized oak tree on the Stony Brook campus.

\section{MATERIALS AND METHODS}

Individuals are assigned to the common asexual genotypes by their electrophoretic profile (Mitter and Futuyma, 1977; Mitter et al., 1979). Each individual was typed for three enzymes, PGM (phosphoglucomutase), PHI (phosphohexose isomerase) and AP-2 (aminopeptidase); for the comparison of isolated maples with mixed woodlot, a fourth enzyme with four electromorphs, G6PDH (glucose-6-phosphate dehydrogenase), was also used. Assay methods for PGM, PHI, and AP- 2 were as described by Mitter and Futuyma (1977). G6PDH (E.C. 1.1.1.49) was run with an electrode buffer of $0.687 \mathrm{M}$ tris and $0.157 \mathrm{M}$ citric acid, and a gel buffer of $22.89 \mathrm{mM}$ tris and $5.22 \mathrm{mM}$ citric acid, at $50 \mathrm{~mA}$. The staining procedure was as described by Shaw and Prasad (1970) with minor modification.

Each putative genotype, as determined by three or four loci, could well prove heterogeneous as more polymorphic loci are scored. The addition of G6PDH to the three loci that we have used heretofore shows greater homogeneity within certain putative clones than others. In a collection of larvae taken in May 1979, 16 were typed as genotype A on the basis of their profile at the PGM, PHI, and AP loci; of these, 12 were homogeneous (CC) for G6PDH. On the basis of the same three loci, 25 were classified as genotype $\mathrm{B}$ and 19 as $\mathrm{Z}$; of these, 21 and 15, respectively, were homogeneous ( $A D$ and $B C$ respectively) for $G 6 \mathrm{PDH}$. Thus it appears that genotypes $\mathrm{A}, \mathrm{B}$, and $\mathrm{Z}$ can be identified with only moderate error. However, 45 individuals putatively typed as genotype $C$ were more highly heterogeneous (22 AC, $10 \mathrm{BC}, 6 \mathrm{AD}, 5 \mathrm{AA}, 2 \mathrm{CC}$ ) for $\mathrm{G} 6 \mathrm{PDH}$. It is, of course, entirely possible that a homogeneous set for these four loci would prove heterogeneous if yet more loci could be scored. Thus if two sets of individuals considered separate clones prove different in some biological respect, it is safe to say that the genetic variance (with respect to that trait) is greater between "clones" than within; but a failure to find differences among "clones" may simply be because of internal genetic heterogeneity.

Adult females were collected by cloth mesh sleeves leading through funnels into holding bottles affixed to the boles that the females ascend (see Schneider, 1980). Larvae were collected from the lower branches of trees by beating the foliage over a beating net. Egg masses were obtained from females caged individually with màles overnight in small paper containers with transparent lids; these females were later typed by electrophoresis, and experiments were performed on larvae from egg masses deposited by females that conformed to the common electrophoretic profiles (of loci PGM, PHI, and AP) designated as genotypes A, B, and C. We assumed from prior experience (Mitter and Futuyma, 1977; Mitter et al., 1979) that the offspring of such females have the same genetic constitution as their mothers. The egg masses were kept outdoors until they hatched.

For the rearing experiment, hatchlings were placed, on the day they hatched, in $4^{\prime \prime} \times 7^{\prime \prime}$ bags of fine mesh polyester fabric that had been placed on twigs of three black oak saplings (Quercus velutina), one chestnut oak (Q. prinus), and four red maples (Acer rubrum) before the hatching time 
of the indigenous Alsophila population. The experimental trees were within $30 \mathrm{~m}$ of each other in a seemingly homogeneous woodlot. For genotypes $\mathrm{B}$ and $\mathrm{C}$, seven bags each with four larvae were placed on each of the trees; clutches from six females of each genotype were used; each clutch was distributed over all eight trees. The larvae were placed on the trees from 25 April to 2 May, with the genotypes paired so they had the same distribution of dates. Only a single clutch of genotype A was available; three bags of five larvae each were placed on two maples and two black oaks on 25 April. On 28 May, when wild larvae were first noticed dropping to the ground, all bagged larvae were removed, weighed, and scored for colour.

The effect of isolation of free-living larvae on a single host species was investigated on four red maple saplings planted at a distance of approximately 50 meters from the nearest woodlot, comprised of oak and maple. In October 1978, the trunk of each isolated maple was banded with two strips of burlap coated with a sticky material that prevented females from ascending the trees to lay eggs. Thus all larvae present on these trees in the following spring had colonised after being wind blown that spring. On 25 May 1979 samples of larvae were taken for electrophoresis from these maples and from the edge of the nearest woodlot.

\section{Results}

\section{(i) Differentiation among stands}

Mitter et al. (1979) reported differences in genotype frequencies among stands of red maple and oak in Nissequogue River State Park, Long Island, New York in 1974 and 1976. Two of these same sites were sampled on 28 May 1979, the maple-dominated stand (RME) and the oak-dominated stand (ROE), which are separated by an ecotone less than $100 \mathrm{~m}$ broad. Significant differentiation is again evident (table 1), although the genotypic composition differs from that reported by Mitter et al.: genotype A, formerly prevalent, was rare in 1979 , and genotypes $\mathrm{C}$ and $\mathrm{B}$, formerly uncommon, were abundant in 1979 .

\section{TABLE 1}

Incidence of common genotypes of Alsophila pometaria in sites RME and ROE, 1979*

Genotype
design:tion

$\begin{array}{cc}\mathrm{A} & \mathrm{AA} \\ \mathrm{B} & \mathrm{AA} \\ \mathrm{C} & \mathrm{AB} \\ \beta & \mathrm{BB} \\ \mathrm{Y} & \mathrm{AB} \\ \text { Others } \dagger & \text { Various }\end{array}$

Electrophoretic profile

PHI AP

$\mathrm{BC} \quad \mathrm{AB}$

$\mathrm{BC} \quad \mathrm{CC}$

$\mathrm{BC} \quad \mathrm{BB}$

$\mathrm{CC} \quad \mathrm{BC}$
Number collected in

$\begin{array}{cc}\text { RME } & \text { ROE } \\ 2 & 1 \\ 4 & 32 \\ 25 & 7 \\ 17 & 31 \\ 6 & 5 \\ 34 & 39\end{array}$

$* \chi^{2}=33 \cdot 150, \mathrm{df}=4$ ("A" combined with "Others" for $\chi^{2}$ analysis), $p<0 \cdot 005$.

+ "Others" includes individuals of 43 electrophoretic profiles, not one of which was represented by more than 5 individuals. 
TABLE 2

Genotypic composition of adult female Alsophila pometaria taken from Maple and Oak Trees, November and December 1977, Stony Brook, New York

\begin{tabular}{|c|c|c|c|c|c|}
\hline \multirow[t]{2}{*}{$\begin{array}{l}\text { Genotype } \\
\text { designation }\end{array}$} & \multicolumn{3}{|c|}{ Electrophoretic profile } & \multirow[t]{2}{*}{ Maples } & \multirow[t]{2}{*}{ Oaks } \\
\hline & PGM & PHI & AP & & \\
\hline A & AA & $\mathrm{BC}$ & $\mathrm{AB}$ & 18 & 44 \\
\hline B & AA & $\mathrm{BC}$ & $\mathrm{CC}$ & 9 & 14 \\
\hline $\mathrm{C}$ & $\mathrm{AB}$ & $\mathrm{BC}$ & BB & 20 & 51 \\
\hline $\mathrm{X}$ & $\mathrm{AB}$ & $\mathrm{BC}$ & $\mathrm{AC}$ & 12 & 23 \\
\hline $\mathrm{Y}$ & $\mathrm{AB}$ & $\mathrm{CC}$ & BB & 35 & 36 \\
\hline $\mathrm{Z}$ & $\mathrm{AB}$ & $\mathrm{CC}$ & $\mathrm{BC}$ & 36 & 50 \\
\hline Others & Various & & & 34 & 49 \\
\hline
\end{tabular}

(ii) Differentiation within stands

Females collected from 15 red maple trees and on 15 oaks paired with the maples, in the mixed species woodlot on the Stony Brook campus on 24-26 November, 3-6 December, and 15 December were analysed by electrophoresis. Table 2 demonstrates that no genetic differentiation by tree species can be discerned. The interocular distance of most of these females was determined under a binocular microscope as a measure of body size. Differences among the six most common genotypes were found (table 3), but no difference among means of females taken from maple versus oak was found for any one genotype, or for all females combined $(t=0.530, \mathrm{df}=304, p>0 \cdot 5)$.

Schneider (1979) found a correlation $(r=0 \cdot 41, p<0 \cdot 005)$ between the average weight of larvae dropping from individual trees in the spring, and that of females climbing the same trees in the subsequent autumn. This implies that females may of ten climb the same tree from which they dropped at the end of their feeding period. Thus if there were substantial mortality of genotypes as a function of tree species, and if there were little dispersal among neighbouring trees in the later instars, neighbouring trees of different species would carry larvae of different genetic composition, and this should be reflected as different genotype frequencies among adult females on those trees in the fall. Under these conditions, moreover, body weight of females of any genotype that fared better on one host species

TABLE 3

Interocular distance $(u)$ of adult female Alsophila pometaria

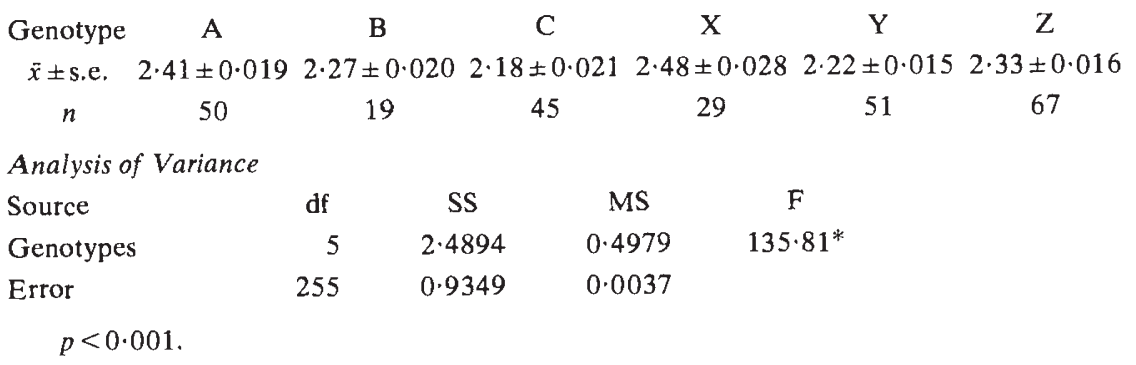


than the other should differ with the host from which they are taken. Our negative results on both these counts imply that dispersal among neighbouring trees is sufficient to prevent any genetic differentiation that may be initiated by selection.

\section{(iii) Differentiation on isolated trees}

Four red maple saplings planted along the side of the biology building $50 \mathrm{~m}$ from the nearest source of wind-blown larvae were banded in the autumn with sticky material to prevent oviposition (see Methods). Nevertheless, the following spring, these trees harboured thousands of larvae; the level of defoliation was indistinguishable by casual examination from that of maples along the edge of the nearby woodlot. Colonisation presumably occurred in the early instars, for the later instars are almost certainly too heavy to have ballooned across the intervening space. A sample of fourth-instar larvae taken from these trees on 25 May differed in genetic composition from a sample taken the same day at the edge of the woodlot (table 4). The difference must be attributed either to differential colonisation by different genotypes, or to differential mortality on the isolated maples.

\section{TABLE 4}

Genetic composition of larval samples from isolated Red Maple trees and nearby woodlot, 25 May 1978

\begin{tabular}{|c|c|c|c|c|c|}
\hline \multicolumn{4}{|c|}{ Electrophoretic profile } & \multirow[t]{2}{*}{ Isolated Maples } & \multirow[t]{2}{*}{ Mixed Woodlot } \\
\hline PGM & PHI & AP-2 & G6PDH & & \\
\hline $\mathrm{AB}$ & $\mathrm{BC}$ & BB & $\mathrm{AC}$ & 14 & 8 \\
\hline$A B$ & $\mathrm{CC}$ & $\mathrm{BC}$ & $\mathrm{BC}$ & 5 & 9 \\
\hline AA & $\mathrm{BC}$ & $\mathrm{CC}$ & $\mathrm{AD}$ & 13 & 5 \\
\hline $\mathrm{AB}$ & $\mathrm{BC}$ & $\mathrm{AC}$ & $\mathrm{AC}$ & 5 & 8 \\
\hline AA & BC & $\mathrm{AB}$ & $\mathrm{CC}$ & 9 & 3 \\
\hline $\mathrm{AB}$ & $\mathrm{BC}$ & BB & $\mathrm{BC}$ & 0) & 6) \\
\hline $\mathrm{AB}$ & $\mathrm{BC}$ & BB & AA & $0>0$ & $6>18$ \\
\hline $\mathrm{AB}$ & $\mathrm{BC}$ & BB & $\mathrm{AD}$ & 0) & 6) \\
\hline Others & & & & 18 & 29 \\
\hline
\end{tabular}

\section{(iv) Reared larvae}

Larvae of genotypes $\mathrm{A}, \mathrm{B}$, and $\mathrm{C}$ were reared from first instar in mesh bags on red maple and black oak foliage; $B$ and $C$ were also reared on a single chestnut oak. The proportion of larvae that survived to 26 May (last instar) was analysed by G-test (Sokal and Rohlf, 1969, p. 601). Comparing only survivorship on red maple and black oak, survivorship differed between hosts and among genotypes, and there was a significant genotype $\times$ host interaction (table 5, fig. 1). The genotypes did not differ in survivorship on black oak, but on red maple the mortality of genotypes B and C was far higher than that of genotype A, which Mitter et al. (1979) reported to be the most prevalent in stands of red maple. Survival of genotypes B and $C$ did not differ on any host species. The survival of $B$ and $C$ combined 
TABle 5

Larval survival of three genotypes of Alsophila pometaria on Red Maple and Black Oak

\begin{tabular}{|c|c|c|c|c|c|c|}
\hline \multirow[b]{2}{*}{ Genotype } & \multicolumn{3}{|c|}{ Maple } & \multicolumn{3}{|c|}{ Oak } \\
\hline & $\begin{array}{l}\text { Initial } \\
\text { number }\end{array}$ & $\begin{array}{c}\text { Number of } \\
\text { survivors }\end{array}$ & Proportion & $\begin{array}{l}\text { Initial } \\
\text { number }\end{array}$ & $\begin{array}{c}\text { Number of } \\
\text { survivors }\end{array}$ & Proportion \\
\hline A & 30 & 23 & 0.77 & 30 & 21 & $0 \cdot 70$ \\
\hline B & 108 & 17 & $0 \cdot 16$ & 84 & 62 & $0 \cdot 74$ \\
\hline $\mathrm{C}$ & 112 & 11 & $0 \cdot 10$ & 84 & 70 & 0.83 \\
\hline
\end{tabular}

G-test:

$\begin{array}{lcc} & \text { df } & \text { G } \\ \text { Genotype }(g) \times \text { Mortality }(m) & 2 & 21 \cdot 99^{*} \\ \text { Genotype }(g) \times \text { Host }(h) & 2 & 0 \cdot 97 \\ \text { Host }(h) \times \text { Mortality }(m) & 1 & 152 \cdot 30^{*} \\ g \times h \times m & \frac{2}{7} & 35 \cdot 68^{*} \\ & \frac{210 \cdot 94^{*}}{}\end{array}$

$p<0 \cdot 005$

did not differ among individual maple trees, but did vary significantly among the three black oak trees $\left(\chi^{2}=6 \cdot 393, \mathrm{df}=2,0 \cdot 025<p<0.05\right)$. Genotypes $\mathrm{B}$ and $\mathrm{C}$ did not differ in survival on the single chestnut oak $\left(\chi^{2}=1 \cdot 150\right.$, $\mathrm{df}=1$ ). These genotypes combined showed lower survival on the single chestnut oak than on the three black oaks taken together $\left(\chi^{2}=22 \cdot 346\right.$, $\mathrm{df}=1, p<0.005$ ).

Live weights of these larvae, taken immediately after removal from the field, differed significantly among genotypes and were significantly higher

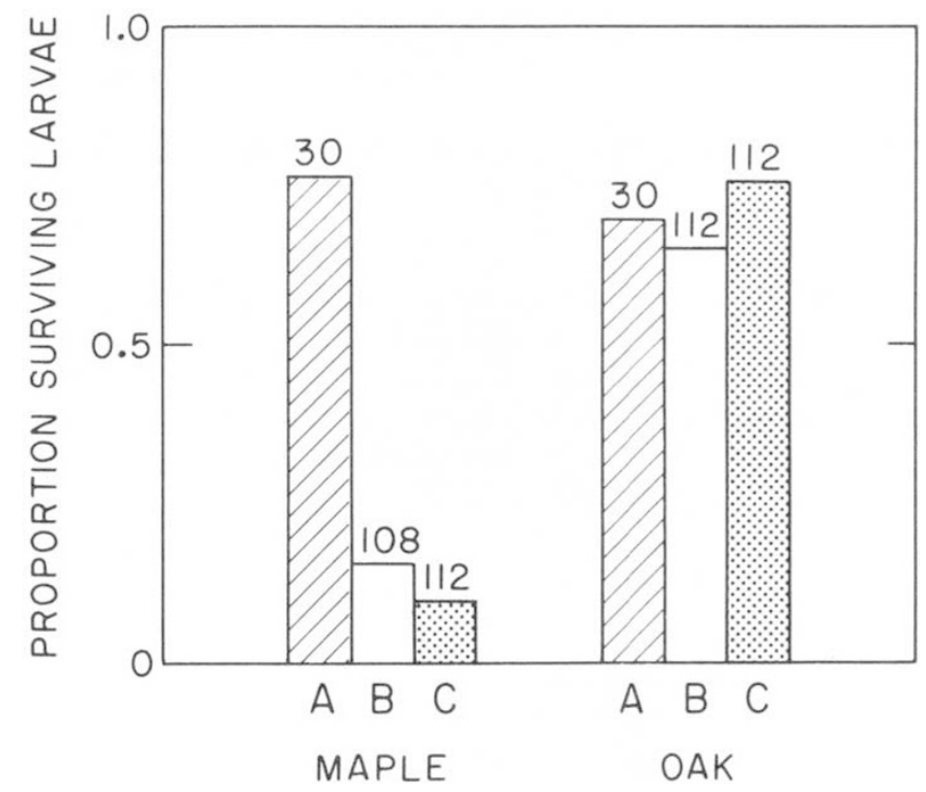

FIG. 1-Proportion of larvae of three genotypes $(\mathrm{A}, \mathrm{B}, \mathrm{C})$ that survived to 28 May, reared in bags on maple and on oak (data combined for 3 black oaks and 1 chestnut oak). Numbers of larvae introduced as first instars are indicated above the bars. 


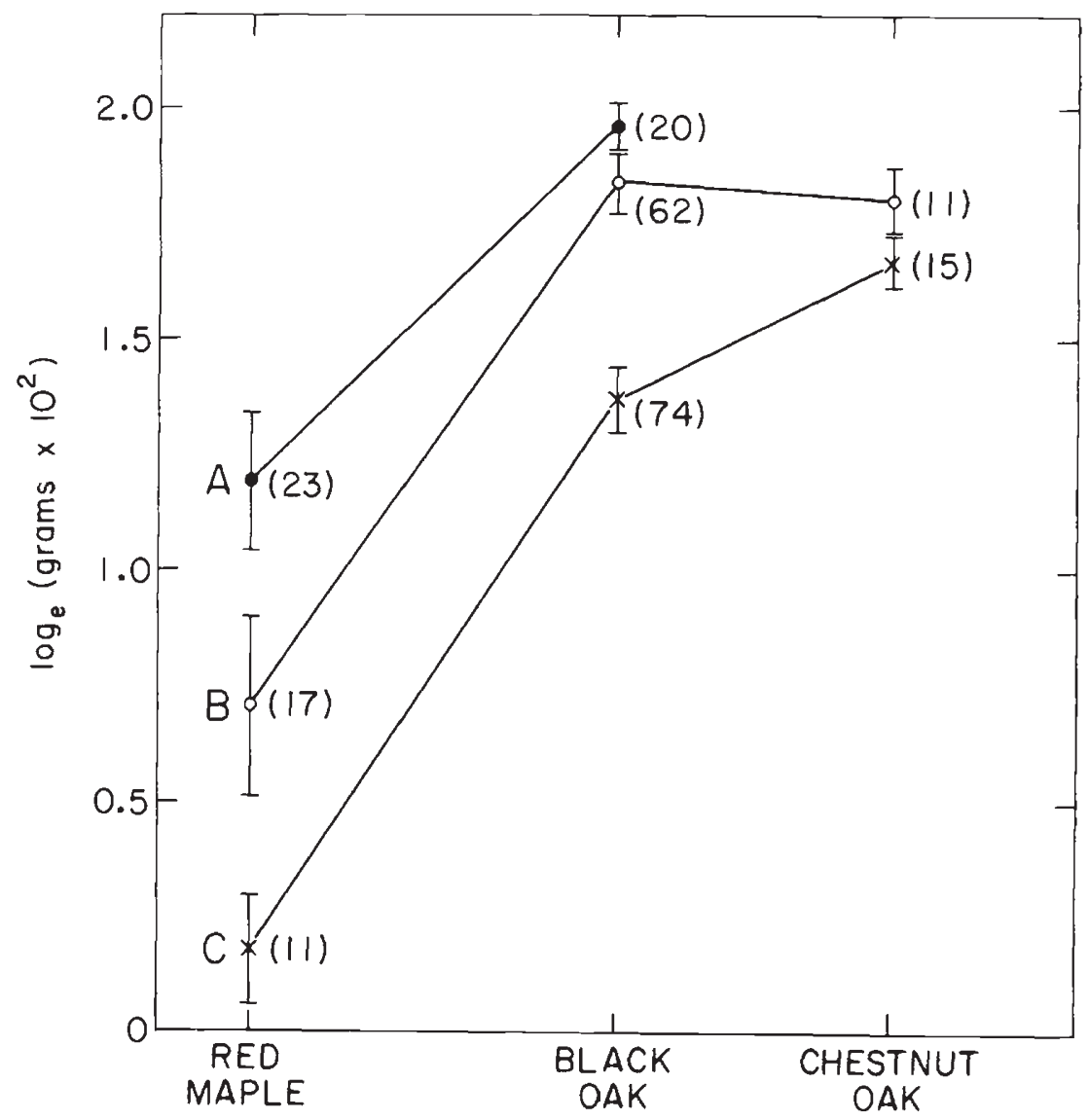

FIG. 2.-Live weight of larvae of three genotypes on 28 May, reared in bags on three species of trees. Vertical bars indicate \pm 1 standard error about the mean.

on oak than on maple (fig. 2). However, the genotype $\times$ host interaction was not significant (table 6); the effect of host on larval weight does not appear to differ among these genotypes. Analysis of variance of the weights of genotypes $\mathrm{B}$ and $\mathrm{C}$ on the three black oak trees revealed no difference between genotypes $(p>0 \cdot 10)$, but significant variation among the individual trees $\left(\mathrm{F}_{2,130}=33 \cdot 125, p<0 \cdot 001\right)$.

\section{TABLE 6}

Analysis of variance of log-transformed larval weight of three genotypes reared on Red Maple and Black Oak

Genotypes

Tree species

Interaction

Error
MS

$2 \cdot 7307$

$18 \cdot 9424$

0.3505

0.2441
F

$11 \cdot 19$

$77 \cdot 60$

$1 \cdot 44$

$p<0.001$

$p<0.001$

$0.10<p<0.25$ 


\section{(v) Melanisation of larvae}

Larvae of Alsophila pometaria usually remain green throughout larval life if reared singly; if reared in groups of two or more, they commonly become melanised (Schneider, 1979). Thus as in certain locusts and other Orthoptera (Uvarov, 1928; Key, 1957) and some other species of Lepidoptera (Iwao, 1968; Drooz, 1966), melanisation is in part a response to crowding, or at least to interactions with other individuals.

Data from a series of small field collections (table 7) suggest that larvae identified as genotype $\mathrm{C}$ on the basis of loci PGM, PHI, and AP are more prone to melanisation than the other common genotypes in these samples, despite the electrophoretic heterogeneity of this class at the G6PDH locus. Although each individual sample is too small for meaningful analysis, the proportion of melanised larvae is higher for genotype $C$ than for other genotypes in every sample; the two-tailed binomial probability of this outcome is 0.032 .

TABLE 7

Numbers of melanised larvae of Alsophila pometaria

\begin{tabular}{lccccc}
\multicolumn{1}{c}{ Genotype } & A & B & C & Y & Z \\
Sample & & & & & \\
Site SB, reared in lab, 1975 & $4 / 17^{*}$ & $20 / 49$ & $15 / 15$ & - & - \\
SB, 1976 & $0 / 8$ & $0 / 5$ & $13 / 22$ & $0 / 3$ & - \\
MT, 1976 & - & $9 / 12$ & $7 / 7$ & - & - \\
ROW, 1976 & - & $8 / 23$ & $6 / 7$ & - & - \\
FR, 1976 & $0 / 3$ & $1 / 14$ & $1 / 7$ & - & - \\
EXRM, 1976 & $2 / 14$ & $1 / 13$ & $2 / 2$ & - & -
\end{tabular}

* Numbers in each cell are (No. melanised)/(Total No.).

Among the larvae reared in mesh bags on maple in 1979, melanisation was less frequent in $B$ and $C$ than in genotype A (fig. 3), presumably because the high mortality of $\mathrm{B}$ and $\mathrm{C}$ on this host reduced the frequency of contact between larvae, which was higher in bags containing genotype A because of its high survival on this host. On the oaks, however, melanisation was far more frequent in $\mathrm{C}$ and $\mathrm{A}$ than in $\mathrm{B}$. The differences among genotypes in the incidence of melanisation on oak are not due to differences in crowding: the distribution of numbers of surviving larvae per bag was similar for the three genotypes.

We have observed, as has Schneider (1979), that melanised larvae of this species have lower average body weight when they initiate pupation than have green larvae. In the only genotype/host species combination ( $B$ on oak) in our bagging experiment in which substantial numbers of both green and melanised larvae were present at the end of the larval period, melanised larvae had significantly lower weight $\left(\bar{x} \ln \left[\mathrm{mg} \times 10^{2}\right]=1.513\right.$, $\left.s^{2}=0.2440, n=26\right)$ than green larvae $\left(\bar{x}=2 \cdot 010, s^{2}=0.1398, n=47\right)$ $(t=4.842, \mathrm{df}=71, p<0.001)$. Among larvae that completed larval life at 4 larvae/bag, green larvae were significantly $(t=4.471, \mathrm{df}=34, p<0.001)$ heavier than melanised larvae $\left(\bar{x}=2 \cdot 194, s^{2}=0.0747, n=18 ; \bar{x}=1.729\right.$, $s^{2}=0 \cdot 1200, n=18$ for green and black respectively). Thus there is some suggestion that over and above the effect of density per se, melanised larvae attain lower weight than larvae that remain green. 


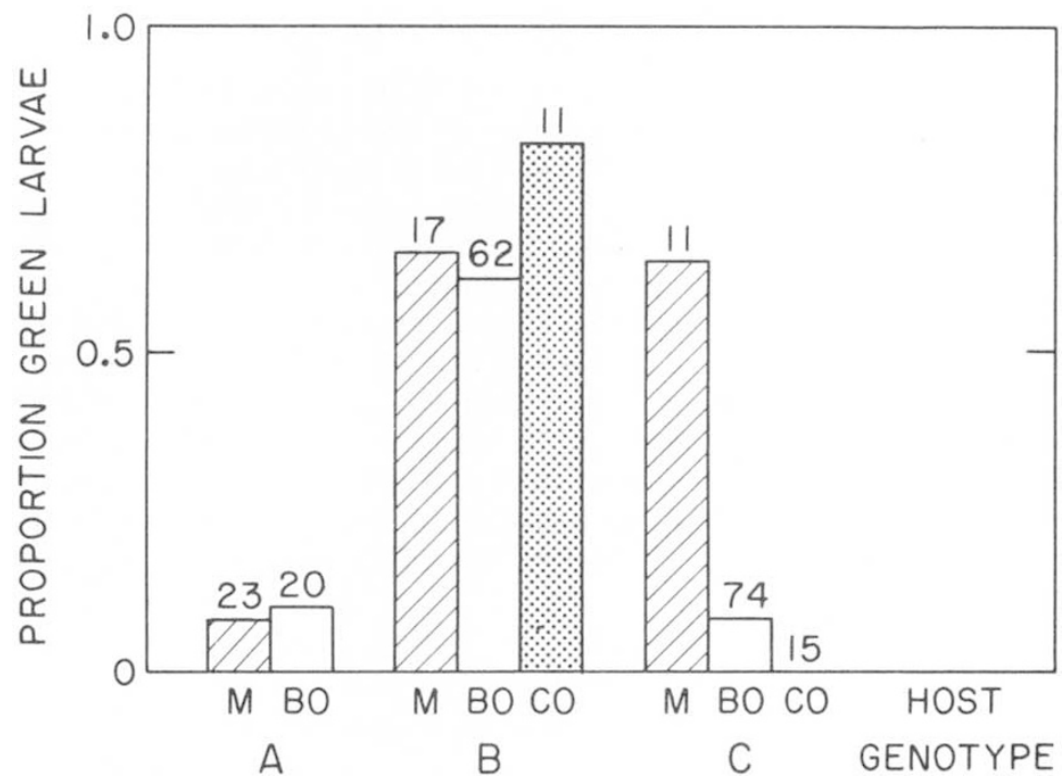

FIG. 3.-Proportion of green larvae among those surviving to 28 May on red maple (M), black oak ( $\mathrm{BO})$, and chestnut oak $(\mathrm{CO})$. Total numbers of surviving larvae of each genotype on each host are indicated above the bars. All larvae of genotype $\mathrm{C}$ on chestnut oak $(\mathrm{CO})$ were melanised.

\section{Discussion}

The experiment described above indicates that at least some of the clonal genotypes of Alsophila pometaria differ substantially in their ability to survive on different species of hosts. The maple-associated genotype, A, survived far better on maple than did two other genotypes. Although our experiment explains why maple stands are not occupied to any great extent by oak-associated genotypes, it did not indicate any disadvantage

TABLE 8

Colouration of larvae of three genotypes reared on Maple $(M)$ and Oak $(O)$

$\begin{array}{cccc}\text { Genotype } & \text { Host } & \text { Green } & \text { Melanised } \\ \text { A } & \text { M } & 3 & 20 \\ & \text { O } & 3 & 18 \\ \text { B } & \text { M } & 11 & 6 \\ & \text { O } & 47 & 26 \\ \text { C } & \text { M } & 7 & 4 \\ & \text { O } & 5 & 80\end{array}$

G-test:

Genotype $\times$ Host

Genotype $\times$ Colour

Colour $\times$ Host

Genotype $\times$ Host $\times$ Colour Interaction 
of the maple-associated genotype A on oak. The phenological disparity between the hatching time of this genotype and bud break of oak may constitute such a disadvantage (Mitter et al., 1979; Schneider, 1980).

We have no evidence that bears directly on the question of why there is clonal diversity within stands. The lack of difference among samples taken from neighbouring trees of different species, together with the existence of differentiation on isolated hosts and among large stands of trees that differ in species composition, strongly suggest that selection can generate genetic differentiation only in environmental patches large enough to overcome the swamping effect of dispersal. If larvae commonly disperse among trees of different species during the course of their feeding, the mosaic of tree species will be a fine-grained environment (Levins, 1968), in which polymorphism cannot be maintained unless there is heterozygous advantage (Strobeck, 1975), which of course cannot account for clonal polymorphism. It is likely that other factors also affect the clonal polymorphism; for example, some genotypes differ in their emergence time in the early winter (Mitter et al., 1979), so that yearly variation in the onset of freezing weather probably causes fluctuations in genotype frequencies.

In addition, it seems likely that the clonal polymorphism is subject to density-dependent selection, for the effect of crowding on melanisation varies among genotypes. Colouration almost certainly affects fitness: melanised larvae pupate earlier (Schneider, 1979), may have a different thermal budget (Hamilton, 1973), may be differentially susceptible to predation (Matthews, 1977; Schneider, 1979), and attain lower weight than green larvae; and pupal weight and fecundity are correlated (Schneider, 1979; Drooz, 1970). There is thus reason to believe that genotype frequencies are affected by abiotic factors such as the onset of winter, variation in host plant suitability, and density-dependent selection.

Acknowledgements-We are grateful to M. Saks, J. Miller, G. Mark, and L. Harshman for assistance in the field and the laboratory, and to D. Catalano and the Long Island State Park and Recreation Commission for permission to collect in the Nissequogue River State Park. The G-tests were performed with the kind assistance of F. J. Rohlf. This research was supported by a grant (DEB 76-20232) from the National Science Foundation. This is Contribution No. 370 from the Program of Ecology and Evolution at the State University of New York at Stony Brook.

\section{REFERENCES}

CUELLAR, 0. 1979. On the ecology of coexistence in parthenogenetic and bisexual lizards of the genus Cnemidophorus. Amer. Zool., 19, 773-786.

Drooz, A. T. 1966. Color studies of elm spanworm larvae. Ann. Entomol. Soc. Amer., 59, 568.

DROOZ, A. T. 1970. Rearing the elm spanworm on oak or hickory. J. Econ. Entomol., 63, 1581-1585.

EMBREE, D. G. 1965. Population dynamics of the winter moth in Nova Scotia, 1954-1962. Mem. Entomol. Soc. Can., 46, 5-55.

FEENY, P. P. 1970. Seasonal changes in oak leaf tannins and nutrients as a cause of spring feeding by winter moth caterpillars. Ecology, 51, 565-581.

Hamilton, w. J. 1973. Life's Color Code. McGraw-Hill, New York. 238 pp.

IWAO, S. 1968. Some effects of grouping in lepidopterous insects. In L'effet de groupe chez les Animaux. Centre National de la Recherche Scientifique, Paris. 391 pp.

JAENIKE, J., PARKER, E. D. JR., AND SELANDER, R. K. 1980. Clonal niche structure in the parthenogenetic earthworm Octolasion tyrtaeum. Amer. Natur., 116, 196-205. 
KEY, K. H. L. 1957. Kentromorphic phases in three species of Phasmatodea. Austr. J. Zool., $5,247-284$.

LEVINS, R. 1968. Evolution in changing environments. Princeton University Press, Princeton, New Jersey. $120 \mathrm{pp}$.

MATTHEWS, E. G. 1977. Signal-based frequency-dependent defense strategies and the evolution of mimicry. Amer. Natur., 111, 213-222.

MitTer, C., AND FUtuYma, D. J. 1977. Parthenogenesis in the fall cankerworm, Alsophila pometaria (Lepidoptera, Geometridae). Entomol. Exp. et Appl., 21, 192-198.

MITTER, C., FUTUYMA, D. J., SCHNEIDER, J. C., AND HARE, J. D. 1979. Genetic variation and host plant relations in a parthenogenetic moth. Evolution, 33, 777-790.

PARKER, E. D. 1979. Ecological implications of clonal diversity in parthenogenetic morphospecies. Amer. Zool., 19, 753-762.

PARKER, E. D., JR., AND SELANDER, R. K. 1976. The organization of genetic diversity in the parthenogenetic lizard Cnemidophorus tesselatus. Genetics, 84, 791-805.

SCHICK, J. M., HOFFMAN, R. J., AND LAMB, A. N. 1979. Asexual reproduction, population structure, and genotype-environment interactions in sea anemones. Amer. Zool., 19, 699-713.

SCHNEIDER, J. C. 1979. Phenological and kentromorphic aspects of the population ecology of the fall cankerworm Alsophila pometaria Harris (Lepidoptera: Geometridae). Ph.D. dissertation, Princeton University. University Microfilms, Ann Arbor, Michigan. 100 pp.

SCHNEIDER, J. C. 1980. The role of parthenogenesis and female aptery in microgeographic, ecological adaptation in the fall cankerworm, Alsophila pometaria Harris (Lepidoptera: Geometridae). Ecology, 61, 1082-1090.

SCUDDAY, J. R. 1973. A new species of lizard of the Cnemidophorus tesselatus group from Texas. J. Herpetol., 75, 363-371.

SHAW, C. R., AND PRASAD, R. 1970. Starch gel electrophoresis of enzymes-a compilation of recipes. Biochem. Genet, 4, 297-320.

SOKAL. R. R., AND ROHLF, F. J. 1969. Biometry. W. J. Freeman, San Francisco. 775 pp.

STROBECK, C. 1975. Selection in a fine-grained environment. Amer. Natur., 109, 419-425.

SUOMALAINEN, E., SAURA, A., AND LOKKI, J. 1976. Evolution of parthenogenetic insects. Evol. Biol., 9, 209-257.

UVAROV, B. P. 1928. Locusts and grasshoppers: a handbook for their study and control. Imperial Bureau of Entomology, London. $352 \mathrm{pp}$.

VARLEY, G. C., AND GRADWEll, G. R. 1956. Oak defoliators in England. Proc. Internat. Congr. Entomol, 10, 133-136.

VARLEy, G. C., AND GRADWell, G. R. 1968. Population models for the winter moth. In ed. T. R. E. Southwood, Insect abundance. Symp. Roy. Ent. Soc. Lond., 4, 132-142.

VRIJENHOEK, R. C. 1978. Coexistence of clones in a heterogeneous environment. Science, 199, 549-552.

VRIJENHOEK, R. C. 1979. Factors affecting clonal diversity and coexistence. Amer. Zool., 19, 787-797. 